\title{
C-KIT Expression in Orbital Cavernous Venous Hemangiomas
}

\author{
Mizhir Atallah ${ }^{1,2,+}$, Natalia Edison ${ }^{3,+}$, Esther Levi ${ }^{2}$, Irit Elmalah ${ }^{3}$ and Daniel Briscoe ${ }^{1,2, *}$ \\ 1 Ophthalmology Department, Emek Medical Center, Afula 18101, Israel; ATALLAHMI@clalit.org.il \\ 2 Laboratory of Ophthalmic Research, Emek Medical Center, Afula 18101, Israel; ester_le1@clalitt.org.il \\ 3 The Tissue Diagnostics and Cancer Research Institute, Emek Medical Center, Afula 18101, Israel; \\ natalia_ed@clalit.org.il (N.E.); elmalaj_ir@clalit.org.il (I.E.) \\ * Correspondence: daniel_br@clalit.org.il; Tel.: +972-4-6494344 \\ + Contributed equally to this work.
}

Citation: Atallah, M.; Edison, N.;

Levi, E.; Elmalah, I.; Briscoe, D. C-KIT Expression in Orbital Cavernous Venous Hemangiomas. Biomolecules 2021, 11, 1199. https://doi.org/ 10.3390/biom11081199

Academic Editors: Nicola Maggio and Efrat Shavit-Stein

Received: 20 July 2021

Accepted: 9 August 2021

Published: 12 August 2021

Publisher's Note: MDPI stays neutral with regard to jurisdictional claims in published maps and institutional affiliations.

Copyright: (C) 2021 by the authors. Licensee MDPI, Basel, Switzerland. This article is an open access article distributed under the terms and conditions of the Creative Commons Attribution (CC BY) license (https:// creativecommons.org/licenses/by/ $4.0 /)$.

\begin{abstract}
Orbital (slow flow) cavernous venous hemangiomas (OCVH) are the most common benign orbital tumors in adults. The c-KIT is a tyrosine kinase receptor, which is expressed on several types of cells, is thought to play a key role in tumor pathogenesis. The purpose of this study was to evaluate the presence of the receptor c-KIT in OCVH. Our retrospective study examined 16 orbital cavernous venous hemangiomas from 16 cases operated on between 2006-2016 at Emek Medical Center. The mean tumor size was $18.4 \mathrm{~mm}$. Symptoms appeared between 6 months and 22 years before operation. All specimens were analyzed for the c-KIT receptor through immunohistochemistry. The c-KIT was expressed by the endothelium in all 16 preparates. Staining was strong in two cases, moderate in six, and weak in eight cases, with no statistically significant correlation between staining and tumor size $(p=0.69)$ or the symptom duration $(p=0.15)$. We conclude that c-KIT may play an important role in the pathogenesis of OCVH. This pilot study is significant in that tumor-targeted therapy such as Imatinib Mesylate and Sunitinib may have a role in treating surgically complicated cases located in the orbital apex. A large multicenter collaborative study is necessary to examine the role of c-KIT in $\mathrm{OCVH}$.
\end{abstract}

Keywords: orbital cavernous hemangioma; c-KIT; immunohistochemistry

\section{Introduction}

Orbital (slow flow) cavernous venous hemangiomas (OCVHs) are the most common benign orbital tumors in adults and constitute between 3-9\% of orbital masses $[1,2]$. They are benign tumors of the orbit and affect both men and women with a mean age of 40-48 years. Usually, they have a typical clinical presentation characterized by slowly developing proptosis, diplopia, a reduction of visual acuity, and the restriction of the visual field. Surgery to remove OCVHs presents a more significant risk of vision loss, especially when the mass is located in the orbital apex. Although they are well characterized clinically [3], their mechanisms of pathogenesis are still elusive. In recent years, however, several studies have investigated the expression of different receptors and markers in OCVHs [4-7] and have thrown some light to their characteristics.

The c-KIT is a tyrosine kinase receptor which is expressed on hematopoietic stem cells and on lung mast cells [8]. It has also been described on different cells including eosinophils [9], basophils [10], human vascular smooth muscle cells [11], epithelial cells [12], and human umbilical vein endothelial cells $[13,14]$. Activation of the c-KIT may result in several cellular responses including proliferation, differentiation, adhesion, survival, programmed cell death, among others. c-KIT is thought to be involved in tumor pathogenesis, including hematologic neoplasia [15], gastrointestinal stromal tumors [16], mastocytosis, seminoma, sarcoma, among others [17-19].

Although several publications have examined the c-KIT in hemangiomas from the body in general, to the best of our knowledge, there are no publications regarding the presence of the c-KIT in Cavernous Venous Hemangiomas or in other types of vascular tumors 
specifically involving the orbit. The purpose of the present study was to examine the presence of c-KIT in OCVH. Several tyrosine kinase inhibitors, including Imatintib, Sunitinib, Gefitinib, and Erlotinib, are currently being used in the treatment of gastrointestinal stromal tumors, lung cancer, esophageal cancer, pancreatic cancer, and adenocarcinoma. The presence of c-KIT receptors in OCVH could open up a whole new non- surgical approach to the treatment of these vision threatening orbital tumors.

\section{Materials and Methods}

All of the experimental protocols of this study were approved by the EMC Ethics Committee review board. We confirm that study number for this study was EMC0086-11. Methods were conducted in accordance with ICH-GCP and Ministry of Health guidelines and was approved by the EMC Ethics Committee review board. Informed consent was waived based on the permission of the EMC Ethics Committee review board, as the research was retrospective and presented no threat to the rights and welfare of the research subjects. The information is not sensitive in nature, and the data are derived from specimens that had previously been excised from the orbit where clinically indicated.

A total of sixteen orbital cavernous venous hemangioma specimens were collected from patients who had been operated on at our medical center between January 2006 and January 2016. Demographics, clinical, and ocular histories were recorded for each of the 16 patients. Tissue was routinely fixed in formalin and was embedded in paraffin. The paraffin sections were cut at $3-\mu \mathrm{m}$ and were routinely stained with Hematoxylin and Eosin. The diagnosis of cavernous hemangioma for each specimen was reconfirmed by a senior pathologist (I.E.).

For staining of c-KIT, formalin-fixed 3- $\mu \mathrm{m}$ paraffin-embedded sections were mounted on Surgipath ${ }^{\mathrm{TM}} \mathrm{X}$-tra ${ }^{\mathrm{TM}}$ Adhesive precleaned micro slides (Leica microsystems, Buffalo Grove, IL, USA) and were processed using an automated immunostainer (Benchmark-ulra, Ventana Medical System, USA.). An anti-c-KIT (CD117) (DAKO, A4502, 1:200 concentration) was used as a primary antibody. Visualization of the bound primary antibodies was performed using the I-View DAB detection KIT (Ventana Medical System). Sections were then counterstained with Gill's hematoxylin, dehydrated, and mounted for microscopic examination. Gastrointestinal stromal tumor served as a positive control. The intensity of the staining was scored as follows: +3 , strong; +2 , moderate; +1 , weak;-negative.

\section{Results}

Histologically, OCVH was identified by large vessels filled with blood cells and lined with flattened endothelium (Figure 1).

All the cases were c-KIT positive with some disparity in the strength of staining. There were two cases with strongly positive staining, six cases with moderate staining, and eight with weak staining. Table 1 and Figure 2A,B show the results of the c-KIT staining. c-KIT was clearly shown to be expressed by the endothelial cells.

Table 1. Summary of c-KIT staining.

\begin{tabular}{cc}
\hline Case & Staining Score \\
\hline 1 & 2 \\
\hline 2 & 2 \\
\hline 3 & 3 \\
\hline 4 & 1 \\
\hline 5 & 2 \\
\hline 6 & 1 \\
\hline
\end{tabular}


Table 1. Cont.

\begin{tabular}{ll}
\hline Case & Staining Score \\
\hline 7 & 2 \\
\hline 8 & 1 \\
\hline 9 & 1 \\
\hline 10 & 1 \\
\hline 11 & 3 \\
\hline 12 & 1 \\
\hline 13 & 1 \\
\hline 14 & 1 \\
\hline 15 & 2 \\
\hline 16 & 2 \\
\hline
\end{tabular}

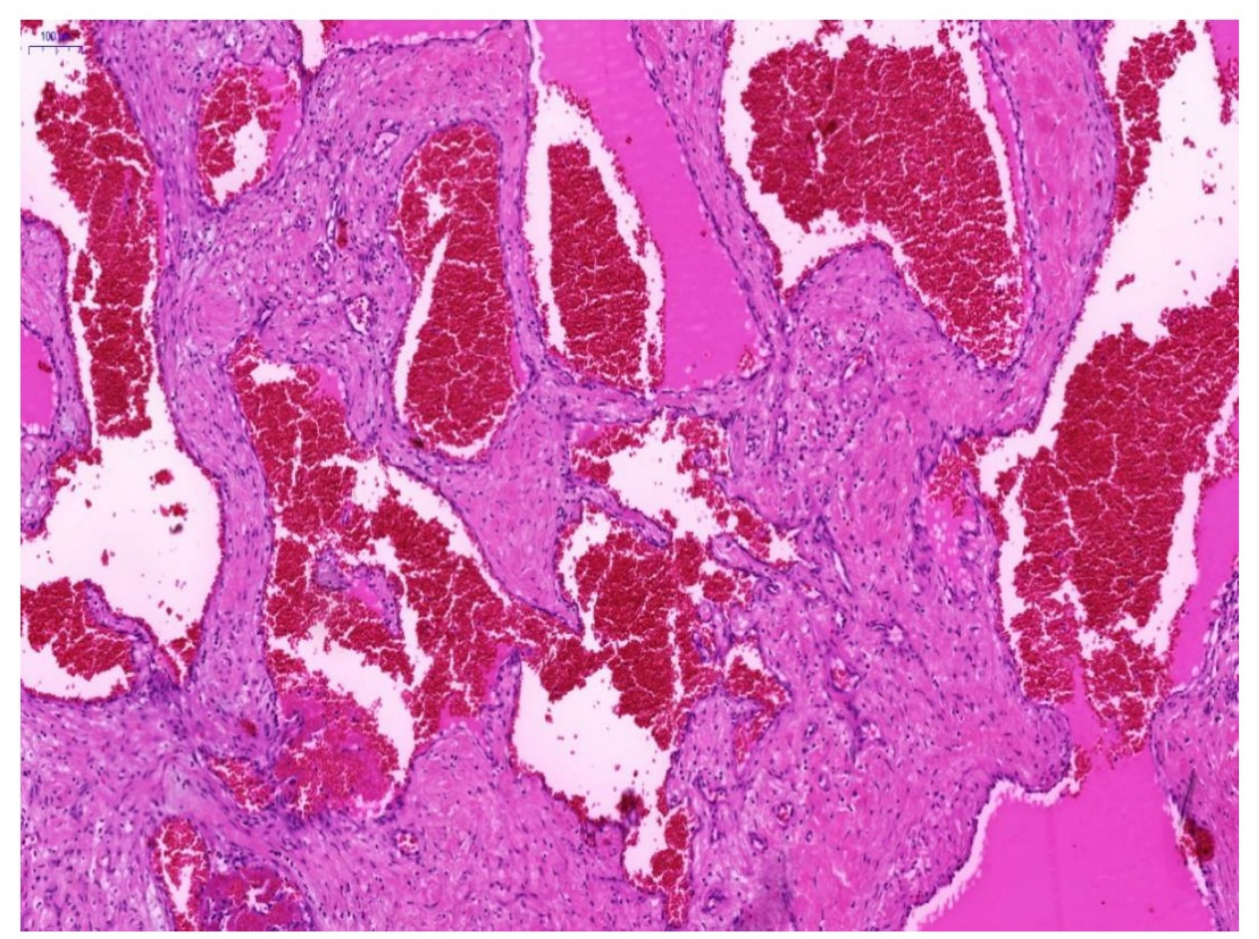

Figure 1. Photomicrograph of a specimen of orbital cavernous hemangioma. Hematoxylin-Eosin staining showed a dilated vascular cavity lined with flattened endothelium and a thick vascular wall. Representative image is presented (magnification $\times 300$. Scale bar $100 \mu \mathrm{m}$ ).

Figure $2 \mathrm{C}$ shows a comparison to the positive control of a gastrointestinal stromal tumor. Clinical features of the patients are presented in Table 2. Patients were 7-78 years of age (mean $39.9 \mathrm{y}$ ), with a female to male ratio of 1:1. The same ratio of 1:1 was also observed regarding the location of the OCVHs in the left or right orbit. The main symptoms at presentation were visual disturbances (8), proptosis (7), and proptosis and ptosis (1). However, 14 patients were found to have proptosis at clinical examination. There were two cases that involved the anterior orbit and the effected eyelid position without proptosis. In the first case, the mass protruded in the upper eyelid, causing mild ptosis. In the second case, the mass was visible in the conjunctival fornix and protruded through the lower eyelid, pushing it up. The symptom duration from onset until the time of the surgery was between 6 months and 22 years. In some cases, there was a small lesion causing no visual impairment. Some of these cases were followed until they began to effect visual function. 
There were 11 patients who had symptoms between 6 months and 2 years before surgery. There were two cases that had symptoms and that were followed for 4 years, and there were three cases that had symptoms and that were followed between 10 and 22 years until eventually undergoing surgery. In seven cases, the tumor was intraconal, and in nine cases, the tumor was extraconal. The tumor size (maximal) ranged from $8 \mathrm{~mm}$ to $28 \mathrm{~mm}$ (mean $18.4 \mathrm{~mm})$.
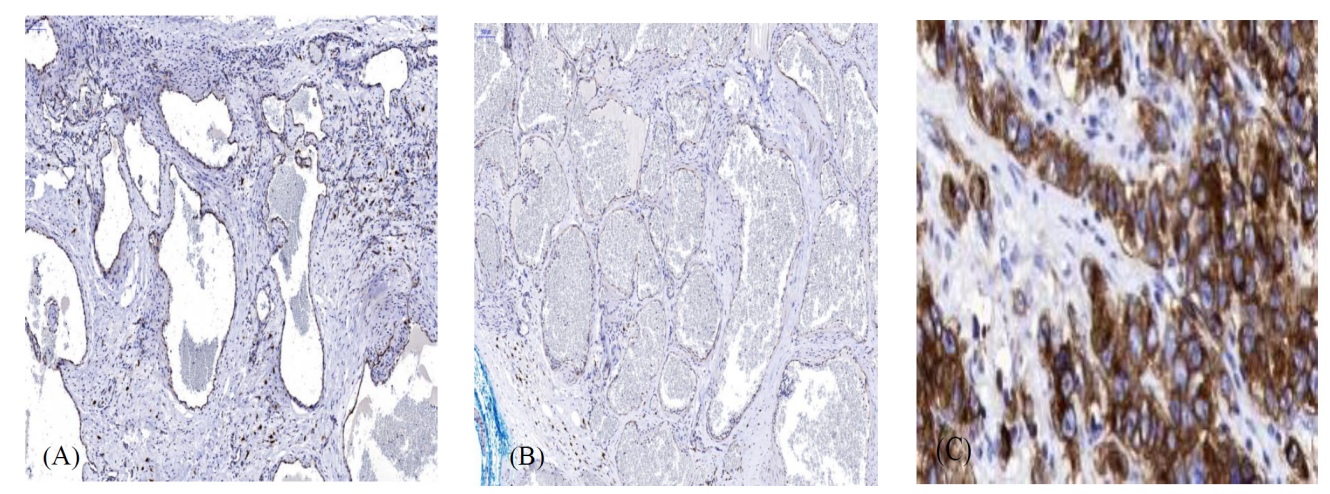

Figure 2. (A). Representative cavernous hemangioma with strong immunohistochemical staining positivity for the c-KIT receptor in endothelial cells. (B). Representative cavernous hemangioma with weak immunohistochemical staining positivity for the c-KIT receptor in endothelial cells. (C). Gastrointestinal stromal tumor served as a positive control. (magnification $\times 300$. Scale bar $100 \mu \mathrm{m}$ ).

Correlation analysis between c-KIT staining and tumor size or duration of symptoms were not statistically significant $(p$ value $=0.6912$ and 0.1474 respectively, analyzed using GraphPad software).

Table 2. Summary of clinical features of the OCVH cases. Proptosis was measured using exophthalmometer and was defined as a globe displacement of $\geq 2 \mathrm{~mm}$ compared to the other side.

\begin{tabular}{|c|c|c|c|c|c|c|c|c|}
\hline Case & Age Range & Sex & $\begin{array}{l}\text { Tumor } \\
\text { Side }\end{array}$ & $\begin{array}{c}\text { Duration of } \\
\text { Symptoms (yrs) }\end{array}$ & $\begin{array}{l}\text { Symptom of } \\
\text { Onset }\end{array}$ & Proptosis & Location & $\begin{array}{l}\text { Tumor Size } \\
\text { (mm) }\end{array}$ \\
\hline 1 & $70^{\prime} \mathrm{s}$ & M & $\mathrm{RT}$ & 1 & $\begin{array}{l}\text { proptosis }+ \\
\text { ptosis }\end{array}$ & $\mathrm{V}$ & Extraconal & $12 \times 10 \times 7$ \\
\hline 2 & $50^{\prime} \mathrm{s}$ & $\mathrm{F}$ & $\mathrm{LT}$ & 2 & proptosis & $\mathrm{V}$ & Intraconal & $15 \times 25 \times 10$ \\
\hline 3 & $30^{\prime} \mathrm{s}$ & $M$ & LT & 10 & proptosis & $\mathrm{V}$ & Intraconal & $15 \times 20 \times 25$ \\
\hline 4 & $30^{\prime} \mathrm{s}$ & $\mathrm{M}$ & $\mathrm{LT}$ & 1.5 & $\begin{array}{c}\text { Visual } \\
\text { disturbance }\end{array}$ & NO & Extraconal & $8 \times 5 \times 7$ \\
\hline 5 & $50^{\prime} \mathrm{s}$ & $\mathrm{F}$ & $\mathrm{RT}$ & 1 & $\begin{array}{c}\text { Visual } \\
\text { disturbance }\end{array}$ & V & Intraconal & $20 \times 20$ \\
\hline 6 & Under10 & $\mathrm{F}$ & RT & 4 & $\begin{array}{c}\text { Visual } \\
\text { disturbance }\end{array}$ & V & Extraconal & $18 \times 10$ \\
\hline 7 & $40^{\prime} \mathrm{s}$ & $\mathrm{F}$ & LE & 1 & $\begin{array}{c}\text { Visual } \\
\text { disturbance }\end{array}$ & V & Extraconal & $15 \times 10 \times 8$ \\
\hline 8 & $20^{\prime} \mathrm{s}$ & $\mathrm{F}$ & LE & 22 & proptosis & $\mathrm{V}$ & Intraconal & $15 \times 15 \times 10$ \\
\hline 9 & $30^{\prime} \mathrm{s}$ & M & RT & 1 & proptosis & $\mathrm{V}$ & Intraconal & $25 \times 15 \times 10$ \\
\hline 10 & $40^{\prime} \mathrm{s}$ & $\mathrm{F}$ & LE & 4 & proptosis & $\mathrm{V}$ & Extraconal & $25 \times 15 \times 15$ \\
\hline 11 & $60^{\prime} \mathrm{s}$ & $M$ & LE & 0.5 & proptosis & $\mathrm{V}$ & Intraconal & $20 \times 15 \times 10$ \\
\hline
\end{tabular}


Table 2. Cont.

\begin{tabular}{ccccccccc}
\hline Case & Age Range & Sex & $\begin{array}{c}\text { Tumor } \\
\text { Side }\end{array}$ & $\begin{array}{c}\text { Duration of } \\
\text { Symptoms (yrs) }\end{array}$ & $\begin{array}{c}\text { Symptom of } \\
\text { Onset }\end{array}$ & Proptosis & Location & $\begin{array}{c}\text { Tumor Size } \\
(\mathbf{m m})\end{array}$ \\
\hline 12 & $40^{\prime} \mathrm{s}$ & $\mathrm{M}$ & $\mathrm{RE}$ & 11 & $\begin{array}{c}\text { Visual } \\
\text { disturbance }\end{array}$ & $\mathrm{V}$ & Extraconal & $28 \times 8$ \\
\hline 13 & $20^{\prime} \mathrm{s}$ & $\mathrm{F}$ & $\mathrm{RE}$ & 1 & $\begin{array}{c}\text { Visual } \\
\text { disturbance }\end{array}$ & $\mathrm{NO}$ & Extraconal & $8 \times 5 \times 3$ \\
\hline 14 & $60^{\prime} \mathrm{s}$ & $\mathrm{M}$ & $\mathrm{RE}$ & 2 & proptosis & $\mathrm{V}$ & Extraconal & $20 \times 15 \times 10$ \\
\hline 15 & $50^{\prime} \mathrm{s}$ & $\mathrm{F}$ & $\mathrm{LE}$ & 1 & $\begin{array}{c}\text { Visual } \\
\text { disturbance }\end{array}$ & $\mathrm{NO}$ & Extraconal & $10 \times 10 \times 8$ \\
\hline 16 & $30^{\prime} \mathrm{s}$ & $\mathrm{M}$ & $\mathrm{RE}$ & 2 & $\begin{array}{c}\text { Visual } \\
\text { disturbance }\end{array}$ & $\mathrm{V}$ & Intraconal & $18 \times 15 \times 15$ \\
\hline
\end{tabular}

\section{Discussion}

In the present, study we have demonstrated the expression of c-KIT in orbital cavernous hemangiomas through immunohistochemical staining. This is the first report of the presence of c-KIT in the endothelial cells of these tumors. The critical roles that c-KIT may play in different functions of the cells and in the pathogenesis of numerous tumors led us to consider studying a potential role in OCVH. Thus, we designed and conducted our study in order to determine whether or not c-KIT is expressed in OCVH and to clarify which cells express it. In our study, which presents the largest series of immunohistochemically studied OCVH in the literature, all the of the 16 cases were positive for c-KIT staining. There was some variation in the strength of the stain between cases according to our protocol. c-KIT was clearly shown to be expressed by endothelial cells, with positive staining in two cases, moderate staining in six, and weak staining in eight cases (Figure 2A,B). Staining disparities between samples might be attributed to methodological causes or to different levels of protein expression. Regarding methodology, we were careful to use standardized techniques for the handling and preparation of the specimens in addition to a uniform staining protocol. However, several explanations might be suggested for real differences in protein expression, including the proliferative capacity of the tumor, the tumor size, the age of patient, and other proteins that might affect, directly or indirectly, the expression of c-KIT. In our study, we could not prove any correlation between the tumor size or the age of patients and the staining strength (data not shown).

Although it is desirable to confirm the immunohistochemical results by proteomic techniques, such as Western blotting, this requires fresh tissue in a tumor that is relatively rare, with only a limited number of cases appearing annually in each center where orbital surgery is performed. Proteomic techniques can also be technically challenging, as other tissue contents, including mast cells, necessarily contribute to the c-KIT protein of the tissue extracts. The use of proteomics and molecular sequencing for the investigation of c-KIT could be the subject of a future prospective multicenter collaborative study using fresh tissue from numerous centers.

Melanoma of the skin and uvea behave differently, and it may be that cavernous hemangiomas in the orbit have different characteristics than cavernous hemangiomas of other parts of the body [20]. Most studies examining c-KIT in angiomas were not specific to cavernous venous hemangiomas and were not from any specific part of the body [21-23]. Our study specifically examined cavernous venous hemangiomas of the orbit.

In recent years, several studies characterizing OCVH immnunohistochemically have been published. Di Tommaso et al. [4] have investigated the presence of the smooth muscle markers, including smooth muscle actin (SMA) and desmin, and the sex steroid receptors, progesterone (PR) and estrogen (ER) receptors, in 12 cases of OCVH. They found that the SMA and desmin were localized in the spindle cells of the vascular walls of all 12 cases and that PR was also observed in all 12 cases. ER was negative in all cases. 
Nagasaka et al. [5] investigated the involvement of several angiogenic factors and their receptors in the growth of nine cases of OCVH. They found that all of the cases were positive for the vascular endothelial growth factor (VEGF). However, another study by Bernatchez and colleagues [24] found that while the basic fibroblast growth factors (bFGF) and the VEGF receptor flk-1, which produce a positive proliferation signal, were expressed in hemangioma, there was no expression of the VEGF receptor flt-1, which negatively regulates endothelial proliferation [25].

Gupta et al. [6] investigated 11 cases of $\mathrm{OCVH}$ with respect to proliferative capacity and receptor expression. They found that the proliferating cell nuclear antigen was positive in 10 out of the 11 cases. The proliferating cell nuclear antigen is considered to be an auxiliary protein for DNA polymerase $\delta$ during the $S$ phase and shows positive a correlation with proliferating endothelial cells [26]. The BcL2, an anti-apoptotic protein, was positive in eight cases. VEGF and PR were each weakly positive in three cases. All of the cases were negative for Mib-1, a monoclonal antibody developed against the Ki-67 protein, which is a proliferation antigen [27], for D2-40, which is a marker of lymphatic endothelium [28] and for ER. Finally, Osaki et al. [7] conducted a comparative immunohistochemical study of infantile hemangioma and OCVH in adults, using different stains for the GLUT-1, endothelial and lymphatic markers, SMA, desmin, and Ki-67. They found no overlapping staining patterns and demonstrated the architectural differences between the two kinds of lesions.

Through immunohistochemical staining, several publications have addressed the presence of c-KIT in normal and transformed human vascular tissues. Lammie A et al. [21] reported c-KIT negativity in normal human endothelia of arteries, veins, and capillaries. Miettinen M and colleagues [22] have investigated c-KIT expression in malignant and benign vascular tumors in addition to fetal tissues. They found that immunohistochemically, more than half of angiosarcomas and the minority of Kaposi sarcoma express c-KIT, whereas this receptor was not detected in benign vascular tumors, with the exception of occasional infantile capillary hemangiomas. Their series included only five cavernous hemangiomas, and it is not stated whether they were from the orbit or from another body location. Another study by Liu L [23] et al. demonstrated that only three out of ten hemangiomas had weak c-KIT positive staining. Similarly, no cases were reported to be from the orbit.

$\mathrm{OCVH}$ is considered as a benign, slow growing tumor. It is traditionally viewed in literature as hamartoma with low proliferative capacities and is attributed to capillary proliferation followed by venous differentiation [3]. An alternative theory suggests that these are vascular malformations that condense into a well-circumscribed tumor [29]. The pathogenesis and origin of this tumor are still elusive with no conceptual consensus in literature. Terminological differences regarding $\mathrm{OCVH}$ and other orbital vascular lesions still exist.

Orbital cavernous hemangiomas, although benign, can be sight threatening depending on their size and location. They can cause gradual compression of the optic nerve as they grow and increase in size. A follow-up of patients with no optic nerve compression is possible, but definitive treatment is surgical removal of the tumor with the consequent risks to sight. The risk of visual damage or diplopia from damage to the extraocular muscles or their innervation during surgery is far greater when the hemangiomas are located in the orbital apex. Apical cavernous hemangiomas in the orbit are often firmly attached to the periosteum, providing a greater surgical challenge and demanding a highly skilled and experienced orbital surgeon with a multidisciplinary team. In these cases, medical treatment could potentially be far less risky than surgery and could provide a better treatment option.

The c-KIT tyrosine kinase receptor is considered to be a protooncogene found on human chromosome 4q11-q12 and on murine chromosome 5 [30]. The binding of its ligand, the stem cell factor [31], leads to the activation of multiple pathways, including phosphatidyl-inositol-3 (PI3)-kinase, phospholipase C (PLC)- $\gamma$, Src kinase, Janus kinase 
(JAK)/Signal Transducers, and the Activators of Transcription (STAT) and mitogen activated protein (MAP) kinase pathways. The resulting cellular responses may include proliferation, differentiation, adhesion, survival, programmed cell death, among others. The cellular response, however, is primarily determined to be by cell type and the environment.

Although loss-of-function mutations of c-KIT have not been reported in humans, the gain of function mutations can result in the development of different tumors. In fact, the first descriptions of the role of c-KIT as a cause of human tumors were reported in hematologic [15] and gastrointestinal stromal tumors [16]. Since then, additional reports have been published, and the mutated c-KIT has been found in mastocytosis, seminoma, sarcoma, among others [17-19]. Moreover, the expression of c-KIT was immunohistochemically shown in germinoma tumors of the brain [32]. The role of c-KIT in tumors is highlighted by the reports that treatment with its inhibitors, the Imatinib Mesylate (Glivec) and Sunitinib (Sutent) (targeted cancer therapy), result in the inhibition of the tumor cells of some cancers [33-39]. It has long been theorized by pathologists that hemodynamic disturbance including thrombosis or bleeding in the cavernous hemangioma may cause the mass to suddenly expand.

Orbital (slow flow) cavernous venous hemangiomas have been well classified in previous publications. [40-44] However Rootman et al. [45] found that thrombosis, acute or chronic, was found in each specimen of their series. Acute fibrin clots were noted in $90 \%$ of samples. About fifty percent of the time, there were between one and five channels with acute thrombosis per specimen.

Thrombin has been shown to mediate mast cell adhesion through the activation of G(i) proteins, phosphoinositol 3-kinase, protein kinase $C$, and mitogen-activated protein kinase pathways [46]. Furthermore, in melanoma cells, up-regulation of the thrombin receptor PAR-1 and the matrix metalloproteinase (MMP)-2, and down regulation of the c-KIT were found to be crucial for the metastatic progression of these cells [47]. This may explain why the cavernous hemangiomas of the orbit can suddenly expand through proliferation of vascular channels and progressive ectasia [3].

In conclusion, our work demonstrates the presence of the c-KIT in Cavernous venous hemangiomas of the orbit. We believe that this study is significant in that a potential promising medical treatment option may be possible using tyrosine kinase inhibitors which are already available. In recent years, a number of tyrosine kinase inhibitors were developed including Imatintib, Sunitinib, Gefitinib, and Erlotinib. These inhibitors were proved effective in treatment of gastrointestinal stromal tumors, lung cancer, esophageal cancer, pancreatic cancer and adenocarcinoma. However further multicenter studies are needed to examine a much larger number of specimens using the same protocol and to explore the mechanism and role of c-KIT in the pathogenesis of OCVH, including c-KIT signal transductions, molecular testing for c-KIT mutations and others. Understanding the pathogenesis mechanisms of OCVH might pave the way for non-invasive treatment modalities such as tumor-targeted therapy. Furthermore, investigation of the expression of C KIT in Cavernous Hemangioma of other specific anatomical locations such as brain or liver will need to be carried out. Should mutated-C KIT be expressed in Cavernous Hemangiomas of the brain and liver, the potential treatment effect could have a far great impact on modern medicine.

Author Contributions: M.A. writing-review and editing. M.A. and N.E. methodology, validation, formal analysis. E.L. performed the experiments, I.E. project administration, supervision. D.B. Conceptulization, review, and editing, funding acquisition. All authors have read and agreed to the published version of the manuscript.

Funding: This research received no external funding.

Institutional Review Board Statement: The study was conducted according to the guidelines of the Declaration of Helsinki, and approved by the Institutional Review Board (or Ethics Committee) of Emek Medical Center, study number EMC0086-11. 
Informed Consent Statement: The Emek Medical Center Ethics Committee review board granted a Waiver of Informed Consent, as the research was retrospective presenting no threat to the rights and welfare of research subjects. The information is not sensitive in nature, and the data are derived from specimens that had been previously excised from the orbit where clinically indicated.

Conflicts of Interest: The authors declare no conflict of interest.

\section{References}

1. Kennedy, R.E. An evaluation of 820 orbital cases. Trans. Am. Ophthalmol. Soc. 1984, 82, 134-157. [PubMed]

2. Bonavolontà, G.; Strianese, D.; Grassi, P.; Comune, C.; Tranfa, F.; Uccello, G.; Iuliano, A. An Analysis of 2480 Space-Occupying Lesions of the Orbit From 1976 to 2011. Ophthal. Plast. Reconstr. Surg. 2013, 29, 79-86. [CrossRef] [PubMed]

3. Harris, G.J.; Jakobiec, F.A. Cavernous hemangioma of the orbit. J. Neurosurg. 1979, 51, 219-228. [CrossRef]

4. Di Tommaso, L.; Scarpellini, F.; Salvi, F.; Ragazzini, T.; Foschini, M.P. Progesterone receptor expression in orbital cavernous hemangiomas. Virchows Arch. 2000, 436, 284-288. [CrossRef]

5. Nagasaka, M.; Naganuma, H.; Satoh, E. Growth potential of orbital cavernous hemangioma suggested by vascular endothelial growth factor and its receptor flk-1. Neurol. Med. Chir. 2007, 47, 5-10. [CrossRef] [PubMed]

6. Gupta, A.; Prabhakaran, V.C.; Dodd, T.; Davis, G.; Selva, D. Orbital Cavernous Haemangiomas: Immunohistochemical Study of Proliferative Capacity, Vascular Differentiation and Hormonal Receptor Status. Orbit 2012, 31, 386-389. [CrossRef] [PubMed]

7. Osaki, T.H.; Jakobiec, F.A.; Mendoza, P.R.; Lee, Y.; Fay, A.M. Immunohistochemical Investigations of Orbital Infantile Hemangiomas and Adult Encapsulated Cavernous Venous Lesions (Malformation Versus Hemangioma). Ophthal. Plast. Reconstr. Surg. 2013, 29, 183-195. [CrossRef]

8. Okayama, Y.; Hunt, T.C.; Kassel, O.; Ashman, L.K.; Church, M.K. Assessment of the anti-c-kit monoclonal antibody YB5.B8 in affinity magnetic enrichment of human lung mast cells. J. Immunol. Methods 1994, 169, 153-161. [CrossRef]

9. Yuan, Q.; Austen, K.F.; Friend, D.S.; Heidtman, M.; Boyce, J.A. Human peripheral blood eosinophils express a functional c-kit receptor for stem cell factor that stimulates very late antigen 4 (VLA-4)-mediated cell adhesion to fibronectin and vascular cell adhesion molecule 1 (VCAM-1). J. Exp. Med. 1997, 186, 313-323. [CrossRef]

10. Columbo, M.; Horowitz, E.M.; Botana, L.M.; MacGlashan, D.W.; Bochner, B.S., Jr.; Gillis, S.; Zsebo, K.M.; Galli, S.J.; Lichtenstein, L.M. The human recombinant c-kit receptor ligand, rhSCF, induces mediator release from human cutaneous mast cells and enhances IgE-dependent media torrelease from both skin mast cells and peripheral blood basophils. J. Immunol. 1992, 149, 599-608.

11. Hollenbeck, S.T.; Sakakibara, K.; Faries, P.L.; Workhu, B.; Liu, B.; Kent, K.C. Stem cell factor and c-kit are expressed by and may affect vascular SMCs through an autocrine pathway. J. Surg. Res. 2004, 120, 288-294. [CrossRef]

12. Peters, E.M.; Maurer, M.; Botchkarev, V.A.; Jensen, K.D.; Welker, P.; Scott, G.A.; Paus, R.K. it is expressed by epithelial cells in vivo. J. Investig. Dermatol. 2003, 121, 976-984. [CrossRef]

13. Aye, M.T.; Hashemi, S.; Leclair, B.; Zeibdawi, A.; Trudel, E.; Halpenny, M.; Fuller, V.; Cheng, G. Expression of stem cell factor and c-kit mRNAin cultured endothelial cells, monocytes and cloned human bone marrowstromal cells (CFU-RF). Exp. Hematol. 1992, 20, 523-527. [PubMed]

14. Broudy, V.C.; Kovach, N.L.; Bennett, L.G.; Lin, N.; Jacobsen, F.W.; Kidd, P.G. Human umbilical vein endothelial cells display high-affinity c-kitreceptors and produce a soluble form of the c-kit receptor. Blood 1994, 83, 2145-2152. [CrossRef] [PubMed]

15. Furitsu, T.; Tsujimura, T.; Tono, T.; Ikeda, H.; Kitayama, H.; Koshimizu, U.; Sugahara, H.; Butterfield, J.H.; Ashman, L.K.; Kanayama, Y.; et al. Identification of mutations in the coding sequence of the proto-oncogene c-kit in a human mast cell eukemia cell line causing ligand-independent activation ofc-kit product. J. Clin. Investig. 1993, 92, 1736-1744. [CrossRef]

16. Hirota, S.; Isozaki, K.; Moriyama, Y.; Hashimoto, K.; Nishida, T.; Ishiguro, S.; Kawano, K.; Hanada, M.; Kurata, A.; Takeda, M.; et al. Gain-of-function mutations of c-kit inhuman gastrointestinal stromal tumors. Science 1998, 279, 577-580. [CrossRef]

17. Nagata, H.; Worobec, A.S.; Oh, C.K.; Chowdhury, B.A.; Tannenbaum, S.; Suzuki, Y.; Metcalfe, D.D. Identification of a point mutation in the catalytic domain of the proto-oncogene c-kit in peripheral blood mononuclear cells of patients who have mastocytosis with an associated hematologic disorder. Proc. Natl. Acad. Sci. USA 1995, 92, 10560-10564. [CrossRef]

18. Longley, B.J.; Tyrrell, L.; Lu, S.Z.; Ma, Y.S.; Langley, K.; Ding, T.G.; Duffy, T.; Jacobs, P.; Tang, L.H.; Modlin, I. Somaticc-kit activating mutation in urticarial pigmentosa and aggressive mastocytosis: Establishment of clonality in a human mast cell neoplasm. Nat. Genet. 1996, 12, 312-314. [CrossRef] [PubMed]

19. Tian, Q.; Frierson, H.F.; Krystal, G.W., Jr.; Moskaluk, C.A. Activating c-kit gene mutations in human germ cell tumors. Am. J. Pathol. 1999, 154, 1643-1647. [CrossRef]

20. Grisanti, S.; Tura, A. Uveal Melanoma. In Noncutaneous Melanoma; Internet; Codon Publications: Brisbane, QLD, Australia, 2018; Chapter 1; pp. 1-18. [CrossRef]

21. Lammie, A.; Drobnjak, M.; Gerald, W.; Saad, A.; Cote, R.; Cordon-Cardo, C. Expression of c-kit and kit ligand proteins in normal human tissues. J. Histochem. Cytochem. 1994, 42, 1417-1425. [CrossRef]

22. Miettinen, M.; Sarlomo-Rikala, M.; Lasota, J. KIT expression in angiosarcomas and fetal endothelial cells: Lack of mutations of exon 11 and exon 17 of C-kit. Mod. Pathol. 2000, 13, 536-541. [CrossRef]

23. Liu, L.; Kakiuchi-Kiyota, S.; Arnold, L.L.; Johansson, S.L.; Wert, D.; Cohen, S.M. Pathogenesis of human hemangiosarcomas and hemangiomas. Hum. Pathol. 2013, 44, 2302-2311. [CrossRef] 
24. Bernatchez, P.N.; Soker, S.H.; Sirois, M.G. Vascular Endothelial Growth Factor Effect on Endothelial Cell Proliferation, Migration, and Platelet-activating Factor Synthesis Is Flk-1-dependent. J. Biol. Chem. 1999, 274, 31047-31054. [CrossRef]

25. Kearney, J.B.; Ambler, C.A.; Monaco, K.A.; Johnson, N.; Rapoport, R.G.; Bautch, V.L. Vascular endothelial growth factor receptor Flt-1 negatively regulates developmental blood vessel formation by modulating endothelial cell division. Blood 2002, 99, $2397-2407$. [CrossRef] [PubMed]

26. Notelet, L.; Houtteville, J.P.; Khoury, S.; Lechevalier, B.; Chapon, F. Proliferating cell nuclear antigen (PCNA) in cerebral cavernomas: An immunocytochemical study of 42 cases. Surg. Neurol. 1997, 47, 364-370. [CrossRef]

27. Scholzen, T.; Gerdes, J. The Ki-67 protein: From the known and the unknown. J. Cell Physiol. 2000, 182, 311-322. [CrossRef]

28. Kahn, H.J.; Bailey, D.; Marks, A. Monoclonal antibody D2-40, a new marker of lymphatic endothelium, reacts with Kaposi's and a subset of angiosarcomas. Mod. Pathol. 2002, 15, 434-440. [CrossRef]

29. Hood, I. Cavernous hemangioma of the orbit. Arch. Ophthalmol. 1970, 83, 49-53. [CrossRef]

30. Yarden, Y.; Kuang, W.J.; Yang-Feng, T.; Coussens, L.; Munemitsu, S.; Dull, T.J.; Chen, E.; Schlessinger, J.; Francke, U.; Ullrich, A. Human proto-oncogenec-kit: A new cell surface receptor tyrosine kinase for an unidentified ligand. EMBO J. 1987, 6, 3341-3351. [CrossRef]

31. Huang, E.; Nocka, K.; Beier, D.R.; Chu, T.Y.; Buck, J.; Lahm, H.W.; Wellner, D.; Leder, P.; Besmer, P. The hematopoietic growth factor KL is encoded by the $\mathrm{Sl}$ locus and is the ligand of the c-kit receptor, the gene product of the W locus. Cell 1990, 63, 225-233. [CrossRef]

32. Sakuma, Y.; Sakurai, S.; Oguni, S.; Satoh, M.; Hironaka, M.; Saito, K. c-kit gene mutations in intracranial germinomas. Cancer Sci. 2004, 95, 716-720. [CrossRef]

33. Oensuu, H.; Roberts, P.J.; Sarlomo-Rikala, M.; Andersson, L.C.; Tervahartiala, P.; Tuveson, D.; Silberman, S.; Capdeville, R.; Dimitrijevic, S.; Druker, B.; et al. Effect of the tyrosine kinase inhibitor STI571 in a patient with a metastatic gastrointestinal stromal tumor. N. Engl. J. Med. 2001, 344, 1052-1056.

34. Mauro, M.J.; Druker, B.J. STI571: Targeting BCRABL as therapy for CML. Oncologist 2001, 6, 233-238. [CrossRef] [PubMed]

35. Druker, B.J.; Tamura, S.; Buchdunger, E.; Ohno, S.; Segal, G.M.; Fanning, S.; Zimmermann, J.; Lydon, N.B. Effects of a selective inhibitor of the Abl tyrosine kinase on the growth of Bcr-Abl positive cells. Nat. Med. 1996, 2, 561-566. [CrossRef] [PubMed]

36. Buchdunger, E.; Cioffi, C.L.; Law, N.; Stover, D.; Ohno-Jones, S.; Druker, B.J.; Lydon, N.B. Abl protein-tyrosine kinase inhibitor STI571 inhibits in vitro signal transduction mediated by c-kit and platelet-derived growth factor receptors. J. Pharmacol. Exp. Ther. 2000, 295, 139-145.

37. Chen, H.; Isozaki, K.; Kinoshita, K.; Ohashi, A.; Shinomura, Y.; Matsuzawa, Y.; Kitamura, Y.; Hirota, S. Imatinib inhibits various types of activating mutant KIT found in gastrointestinal stromal tumors. Int. J. Cancer 2003, 105, 130-135. [CrossRef]

38. Tuveson, D.A.; Willis, N.A.; Jacks, T.; Griffin, J.D.; Singer, S.; Fletcher, C.D.; Fletcher, J.A.; Demetri, G.D. STI571 inactivation of the gastrointestinal stromal tumor c-KIT oncoprotein: Biological andclinical implications. Oncogene 2001, 20, 5054-5058. [CrossRef] [PubMed]

39. Demetri, G.D.; von Mehren, M.; Blanke, C.D.; Van den Abbeele, A.D.; Eisenberg, B.; Roberts, P.J.; Heinrich, M.C.; Tuveson, D.A.; Singer, S.; Janicek, M.; et al. Efficacy and safety of imatinibmesylate in advanced gastrointestinalstromaltumors. N. Engl. J. Med. 2002, 347, 472-480. [CrossRef]

40. Enjolras, O. Classification and management of the various superficial vascular anomalies: Hemangiomas and vascular malformations. J. Dermatol. 1997, 24, 701-710. [CrossRef]

41. Garzon, M.C.; Huang, J.T.; Enjolras, O.; Frieden, I.J. Vascular malformations: Part, I. J. Am. Acad. Dermatol. 2007, 56, 353-370. [CrossRef]

42. Mulliken, J.B.; Glowacki, J. Hemangiomas and vascular malformations in infants and children: A classification based on endothelial characteristics. Plast. Reconstr. Surg. 1982, 69, 412-422. [CrossRef]

43. Legiehn, G.M.; Heran, M.K. Venous malformations: Classification, development, diagnosis, and interventional radiologic management. Radiol. Clin. N. Am. 2008, 46, 545-597. [CrossRef]

44. Jackson, I.T.; Carreño, R.; Potparic, Z.; Hussain, K. Hemangiomas, vascular malformations, and lymphovenous malformations: Classification and methods of treatment. Plast. Reconstr. Surg. 1993, 91, 1216-1230. [CrossRef] [PubMed]

45. Rootman, D.B.; Heran, M.K.; Rootman, J.; White, V.A.; Luemsamran, P.; Yucel, Y.H. Cavernous venous malformations of the orbit (so-called cavernous haemangioma): A comprehensive evaluation of their clinical, imaging and histologic nature. Br. J. Ophthalmol. 2014, 98, 880-888. [CrossRef] [PubMed]

46. Vliagoftis, H. Thrombin induces mast cell adhesion to fibronectin: Evidence for involvement of protease-activated receptor-1. J. Immunol. 2002, 169, 4551-4558. [CrossRef] [PubMed]

47. Leslie, M.C.; Bar-Eli, M. Regulation of Gene Expression in Melanoma: New Approaches for Treatment. J. Cell Biochem. 2005, 94, 25-38. [CrossRef] [PubMed] 